\title{
Non-Hodgkin's Lymphoma among Patients Infected with Human Immunodeficiency Virus: The Experience of a Single Center in Brazil
}

\author{
Paula Yurie Tanaka, Luis Fernando Pracchia, Edenilson Eduardo Calore
}

Int J Hematol. 2006;84(4):337-342.

"With the EPOCH regimen, Little et al described the best response rate $(87 \%)$ and OS rate $(87 \%$ at 56 months) to date for patients with CD 4 cell counts $>100 / \mu \mathrm{L}$; however, the outcomes were worse for patients with CD4 cell counts $<100 / \mu \mathrm{L}$ (OS rate of $16 \%$ at 56 months) [13-15]."

The authors wish to correct the information in their manuscript to:

"With the EPOCH regimen, Little et al described the best response rate $(87 \%)$ and OS rate $(87 \%$ at 53 months) to date for patients with CD4 cell counts $>100 / \mu \mathrm{L}$; however, the outcomes were worse for patients with CD4 cell counts $<100 / \mu \mathrm{L}$ (OS rate of $16 \%$ at 53 months) [13-15]." 